Introduction to Internal Combustion Engines 
Other Macmillan titles of related interest

E. M. Goodger, Combustion Calculations: Theory, worked examples and problems

E. M. Goodger, Principles of Engineering Thermodynamics, second edition

E. M. Goodger and R. A. Vere, Aviation Fuels Technology

Richard T. C. Harman, Gas Turbine Engineering: Applications, cycles and characteristics

N. Watson and M. S. Janota, Turbocharging the Internal Combustion Engine 


\section{Introduction to Internal Combustion Engines}

Richard Stone

Brunel University

Uxbridge, Middlesex

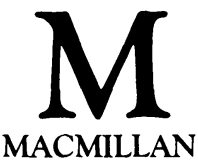


C Richard Stone 1985

All rights reserved. No reproduction, copy or transmission of this publication may be made without written permission.

No paragraph of this publication may be reproduced, copied or transmitted save with written permission or in accordance with the provisions of the Copyright Act 1956 (as amended).

Any person who does any unauthorised act in relation to this publication may be liable to criminal prosecution and civil claims for damages.

First published 1985

Published by

Higher and Further Education Division

MACMILLAN PUBLISHERS LTD

Houndmills, Basingstoke, Hampshire RG21 2XS

and London

Companies and representatives

throughout the world

British Library Cataloguing in Publication Data

Stone, Richard

Introduction to internal combustion engines.

1. Internal combustion engine

I. Title

621.43 TJ785

ISBN 978-0-333-37594-5

ISBN 978-1-349-17910-7 (eBook)

DOI 10.1007/978-1-349-17910-7 


\section{Contents}

Preface $\quad x$

Acknowledgements xii

Notation xiii

1 Introduction 1

1.1 Fundamental operating principles 1

1.2 Early internal combustion engine development 6

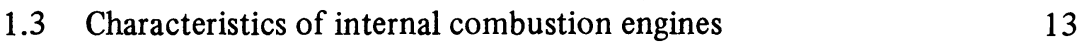

$\begin{array}{ll}1.4 & \text { Additional types of internal combustion engine } \\ \end{array}$

$\begin{array}{lll}\text { 1.4.1 The Wankel engine } & 16\end{array}$

$\begin{array}{ll}\text { 1.4.2 Stratified charge engines } & 17\end{array}$

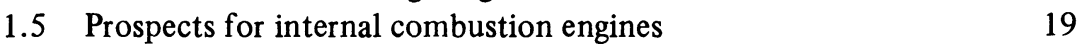

2 Thermodynamic Principles $\quad 22$

2.1 Introduction and definitions of efficiency 22

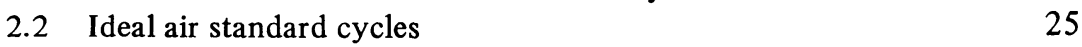

2.2.1 The ideal air standard Otto cycle 25

2.2.2 The ideal air standard Diesel cycle 26

2.2.3 The ideal air standard Dual cycle 29

2.2.4 The ideal air standard Atkinson cycle 29

2.3 Comparison between thermodynamic and mechanical cycles 30

2.4 Additional performance parameters for internal combustion engines $\quad 32$

2.5 Fuel-air cycle $\quad 35$

2.6 Computer models $\quad 39$

2.7 Conclusions 41

2.8 Examples $\quad 43$

2.9 Problems 45

3 Combustion and Fuels $\quad 47$

3.1 Introduction 47

3.2 Combustion chemistry and fuel chemistry 50 
3.3 Combustion thermodynamics $\quad 55$

$\begin{array}{lll}3.4 & \text { Dissociation } & 60\end{array}$

3.5 Combustion in spark ignition engines 62

3.5.1 Normal combustion 62

3.5.2 Abnormal combustion $\quad 64$

3.6 Combustion in compression ignition engines 65

3.7 Fuels and additives 66

$\begin{array}{lll}\text { 3.7.1 Characteristics of petrol } & 67\end{array}$

$\begin{array}{ll}\text { 3.7.2 Characteristics of diesel fuel } & 73\end{array}$

3.8 Engine emissions 76

$\begin{array}{ll}3.9 \text { Combustion modelling } & 79\end{array}$

$\begin{array}{lll}3.9 .1 & \text { Introduction } & 79\end{array}$

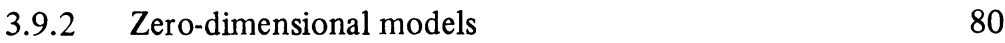

3.9.3 Quasi-dimensional models $\quad 82$

3.10 Conclusions $\quad 84$

3.11 Examples $\quad 84$

3.12 Problems $\quad 94$

4 Spark Ignition Engines $\quad 96$

4.1 Introduction 96

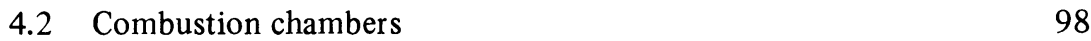

4.2.1 Conventional combustion chambers 98

4.2.2 High compression ratio combustion chambers 104

$\begin{array}{lll}4.3 & \text { Ignition systems } & 107\end{array}$

$\begin{array}{ll}4.4 \text { Carburettors } & 111\end{array}$

4.4.1 Variable jet carburettor $\quad 115$

$\begin{array}{ll}\text { 4.4.2 Fixed jet carburettor } & 116\end{array}$

4.5 Fuel injection 121

4.6 Electronic control of engines 122

$\begin{array}{lll}4.7 & \text { Conclusions } & 127\end{array}$

4.8 Example 128

4.9 Problems 129

5 Compression Ignition Engines $\quad 131$

5.1 Introduction 131

5.2 Direct injection (DI) systems 132

$\begin{array}{lll}5.3 & \text { Indirect injection (IDI) systems } & 137\end{array}$

5.4 Cold starting of compression ignition engines 141

$\begin{array}{lll}5.5 & \text { Fuel injection equipment } & 145\end{array}$

$\begin{array}{lll}\text { 5.5.1 Fuel injectors } & 147\end{array}$

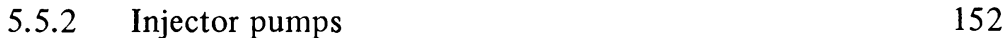

5.5.3 Interconnection of pumps and injectors 157

$\begin{array}{ll}5.6 \text { Conclusions } & 161\end{array}$

$\begin{array}{lll}5.7 & \text { Example } & 162\end{array}$

5.8 Problems 163 
6 Induction and Exhaust Processes 165

$\begin{array}{lll}6.1 \text { Introduction } & 165\end{array}$

$\begin{array}{ll}6.2 \text { Valve gear } & 166\end{array}$

$\begin{array}{lll}6.2 .1 & \text { Valve types } & 166\end{array}$

6.2.2 Valve-operating systems 166

6.2.3 Flow characteristics of poppet valves 170

$\begin{array}{lll}6.2 .4 & \text { Valve timing } & 173\end{array}$

$\begin{array}{ll}\text { 6.2.5 Dynamic behaviour of valve gear } & 175\end{array}$

6.3 Unsteady compressible fluid flow 178

$\begin{array}{ll}6.4 \text { Manifold design } & 181\end{array}$

$\begin{array}{lll}6.5 \text { Silencing } & 185\end{array}$

$\begin{array}{lll}6.6 \text { Conclusions } & 187\end{array}$

$\begin{array}{ll}6.7 \text { Problems } & 187\end{array}$

7 Turbocharging $\quad 188$

$\begin{array}{lll}7.1 \text { Introduction } & 188\end{array}$

$\begin{array}{ll}7.2 & \text { Radial flow and axial flow machines } \\ 7.31\end{array}$

7.3 Turbocharging the compression ignition engine 201

7.4 Turbocharging the spark ignition engine 206

$\begin{array}{ll}7.5 \text { Conclusions } & 212\end{array}$

$\begin{array}{ll}7.6 \text { Examples } & 213\end{array}$

$\begin{array}{lll}7.7 & \text { Problems } & 217\end{array}$

$\begin{array}{lll}8 & \text { Mechanical Design Considerations } & 218\end{array}$

$\begin{array}{ll}8.1 \text { Introduction } & 218\end{array}$

8.2 The disposition and number of the cylinders 219

8.3 Cylinder block and head materials 223

8.4 The piston and rings 226

8.5 The connecting-rod, crankshaft, camshaft and valves 228

$\begin{array}{ll}8.6 & 232\end{array}$

$\begin{array}{lll}\text { 8.6.1 Lubrication } & 232\end{array}$

8.6.2 Bearing materials $\quad 235$

$\begin{array}{lll}8.7 & \text { Conclusions } & 239\end{array}$

9 Experimental Facilities $\quad 240$

$\begin{array}{lll}9.1 \text { Introduction } & 240\end{array}$

9.2 Simple engine test rig 241

$\begin{array}{ll}\text { 9.2.1 Dynamometers } & 241\end{array}$

9.2.2 Fuel-consumption measurement 244

9.2.3 Air flow rate 246

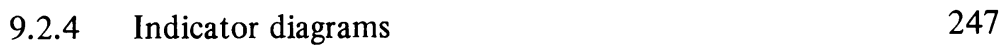

9.2.5 Indicated power 249

9.2.6 Engine test conditions 251

$\begin{array}{ll}\text { 9.2.7 Energy balance } & 252\end{array}$

9.3 Experimental accuracy 253 
$\begin{array}{lll}9.4 & \text { Advanced test systems } & 255\end{array}$

9.5 Conclusions 260

10 Case Studies $\quad 261$

$\begin{array}{ll}10.1 \text { Introduction } & 261\end{array}$

10.2 Jaguar V12 HE engine 261

$\begin{array}{ll}\text { 10.2.1 Background } & 261\end{array}$

10.2.2 Engine development 263

10.2.3 Jaguar V12 ignition and mixture preparation

10.2.4 Combustion chamber development $\quad 269$

10.3 Chrysler 2.2 litre spark ignition engine 272

$\begin{array}{ll}\text { 10.3.1 Background } & 272\end{array}$

10.3.2 The cylinder head $\quad 272$

10.3.3 The cylinder block and associated components 276

$\begin{array}{ll}\text { 10.3.4 Combustion control } & 277\end{array}$

$\begin{array}{ll}\text { 10.3.5 Catalyst systems } & 277\end{array}$

10.4 Ford 2.5 litre DI Diesel engine 281

$\begin{array}{ll}\text { 10.4.1 Background } & 281\end{array}$

10.4.2 Description $\quad 282$

10.4.3 The combustion system $\quad 284$

Appendix A: The Use of SI Units 288

Appendix B: Answers to Numerical Problems 291

Appendix C: Engine Specifications $\quad 292$

C.1 Sulzer marine compression ignition engines 292

$\begin{array}{ll}\text { C.2 Ford 'Dover' 90-150 series direct injection } & \\ \text { compression ignition engines } & 294\end{array}$

C.3 Rolls Royce CV12 direct injection compression ignition engine 295

C.4 Ford V6 'Essex' spark ignition engine 295

C.5 Chrysler $875 \mathrm{~cm}^{3}$ spark ignition engine 296

C.6 Jaguar V12 spark ignition engine 297

C.7 Chrysler 2.2 litre spark ignition engine 297

C.8 Fiat-Sofim indirect injection compression ignition engine 298

C.9 Ford 2.5 litre DI Diesel engine 299

C.10 Volvo-Penta 2-stroke spark ignition outboard

Appendix D: Stratified Charge Engines $\quad 302$

Appendix E: Engine tuning 305

E.1 Introduction 305

E.2 Tuning for spark ignition engine economy 305

E.3 Tuning for spark ignition engine output 307 
CONTENTS

Bibliography

References

312

Index

315 


\section{Preface}

This book aims to provide for students and engineers the background that is presupposed in many articles, papers and advanced texts. Since the book is primarily aimed at students, it has sometimes been necessary to give only outline or simplified explanations. However, numerous references have been made to sources of further information.

Internal combustion engines form part of most thermodynamics courses at Polytechnics and Universities. This book should be useful to students who are following specialist options in internal combustion engines, and also to students at earlier stages in their courses - especially with regard to laboratory work.

Practising engineers should also find the book useful when they need an overview of the subject, or when they are working on particular aspects of internal combustion engines that are new to them.

The subject of internal combustion engines draws on many areas of engineering: thermodynamics and combustion, fluid mechanics and heat transfer mechanics, stress analysis, materials science, electronics and computing. These disparate areas are drawn together in the first eight chapters, so that these chapters are best read in sequence. However, internal combustion engines are not just subject to thermodynamic or engineering considerations - the commercial (marketing, sales etc.) and economic aspects are also important, and these are discussed as they arise.

Chapter 1 provides an introduction, with definitions of engine types and operating principles. The essential thermodynamics is provided in chapter 2 , while chapter 3 provides the background in combustion and fuel chemistry. The differing needs of spark ignition engines and compression ignition engines are discussed in chapters 4 and 5 respectively.

Chapter 6 describes how the induction and exhaust processes are controlled, and this leads to chapter 7 , where turbochargers are discussed. The remaining chapters can be read in parallel with the earlier chapters. Some of the mechanical and materials aspects are discussed in chapter 8 , while chapter 9 covers some experimental techniques. Finally, chapter 10 provides three case studies that should remain topical for some time. 
This book is the product of information gained from numerous sources, and it would be invidious to acknowledge individuals. However, I should like to express my gratitude to Dr Neil Watson of Imperial College, London, and to Dr Neil Richardson of Jesus College, Oxford, for reading and commenting on the drafts. I must also express my thanks to the typists, in particular to Mrs Gill Oxley who typed most of the material.

In conclusion, I would welcome any criticism and suggestions concerning either the detail of the book or the overall concept. 


\section{Acknowledgements}

The author and publisher wish to thank the following, who have kindly given permission for the use of copyright material.

Dr W. J. D. Annand (University of Manchester) for seven figures from W. J. D. Annand and G. E. Roe, Gas Flow in the Internal Combustion Engine, published by Foulis, Yeovil, 1974.

Atlantic Research Associates, Tunbridge Wells, and Martin H. Howarth for three figures from M. H. Howarth, The Design of High Speed Diesel Engines, published by Constable, London, 1966.

Blackie and Son Ltd, Glasgow, for three figures from H. R. Ricardo and J. G. G. Hempson,

The High Speed Internal Combustion Engine, 1980.

Butterworths, Guildford, for five figures from K. Newton, W. Steeds and T. K. Garrett, The Motor Vehicle, 10th edn, 1983.

Ford of Europe, Inc., Brentwood, for eleven figures from Ford technical publications.

Froude Consine Ltd, Worcester, for two figures from Publication No. 526/2.

GKN Engine Parts Division, Maidenhead, for a figure from Publication No. EPD 82100.

Hutchinson Publishing Group Ltd, London, for a figure from A. Baker, The Component

Contribution (co-sponsored by the AE Group), 1979.

Johnson Matthey Chemicals Ltd, Royston, for three figures from Catalyst Systems for

Exhaust Emission Control from Motor Vehicles.

Longmans Group Ltd, Harlow, for four figures from G. F. C. Rogers and Y. R. Mayhew, Engineering Thermodynamics, 3rd end, 1980; two figures from H. Cohen, G. F. C. Rogers and H. I. H. Saravanamuttoo, Gas Turbine Theory, 2nd edn, 1972.

Lucas CAV Ltd, London, for eight figures from CAV Publications 586, 728, 730, 773 and $C 2127 E$, and a press release photograph.

Lucas Electrical Ltd, Birmingham, for two figures from publications PLT 6339 (Electronic Fuel Injection) and PLT 6176 (Ignition).

MIT Press, Cambridge, Massachusetts, and Professor C. F. Taylor for a figure from

C. F. Taylor, The Internal Combustion Engine in Theory and Practice, 1966/8.

Oxford University Press for two figures from Singer's History of Technology.

Patrick Stephens Ltd, Cambridge, for three figures from A. Allard, Turbocharging and

Supercharging, 1982.

Pergamon Press Ltd, Oxford, for a figure from R. S. Benson and N. D. Whitehouse,

Internal Combustion Engines, 1979; three figures from H. Daneshyar, One-Dimensional Compressible Flow, 1976.

Plenum Press, New York, and Professor John B. Heywood (MIT) for a figure from

J. B. Heywood, Combustion Modelling in Reciprocating Engines, 1980.

Purnell Books, Bristol, for a figure from A. F. Evans, The History of the Oil Engine.

Society of Automotive Engineers, Warrendale, Pennsylvania, for ten figures and copy

from SAE 790291, SAE 820167, SAE 821578 and Prepr. No. 61A (1968).

Sulzer Brothers Ltd, Winterthur, Switzerland, for three figures from the Sulzer

Technical Review, Nos 1 and 3 (1982).

Material is acknowledged individually throughout the text of the book.

Every effort has been made to trace all copyright holders but, if any have been inadvertently overlooked, the publisher will be pleased to make the necessary arrangements at the first opportunity. 


\section{Notation}

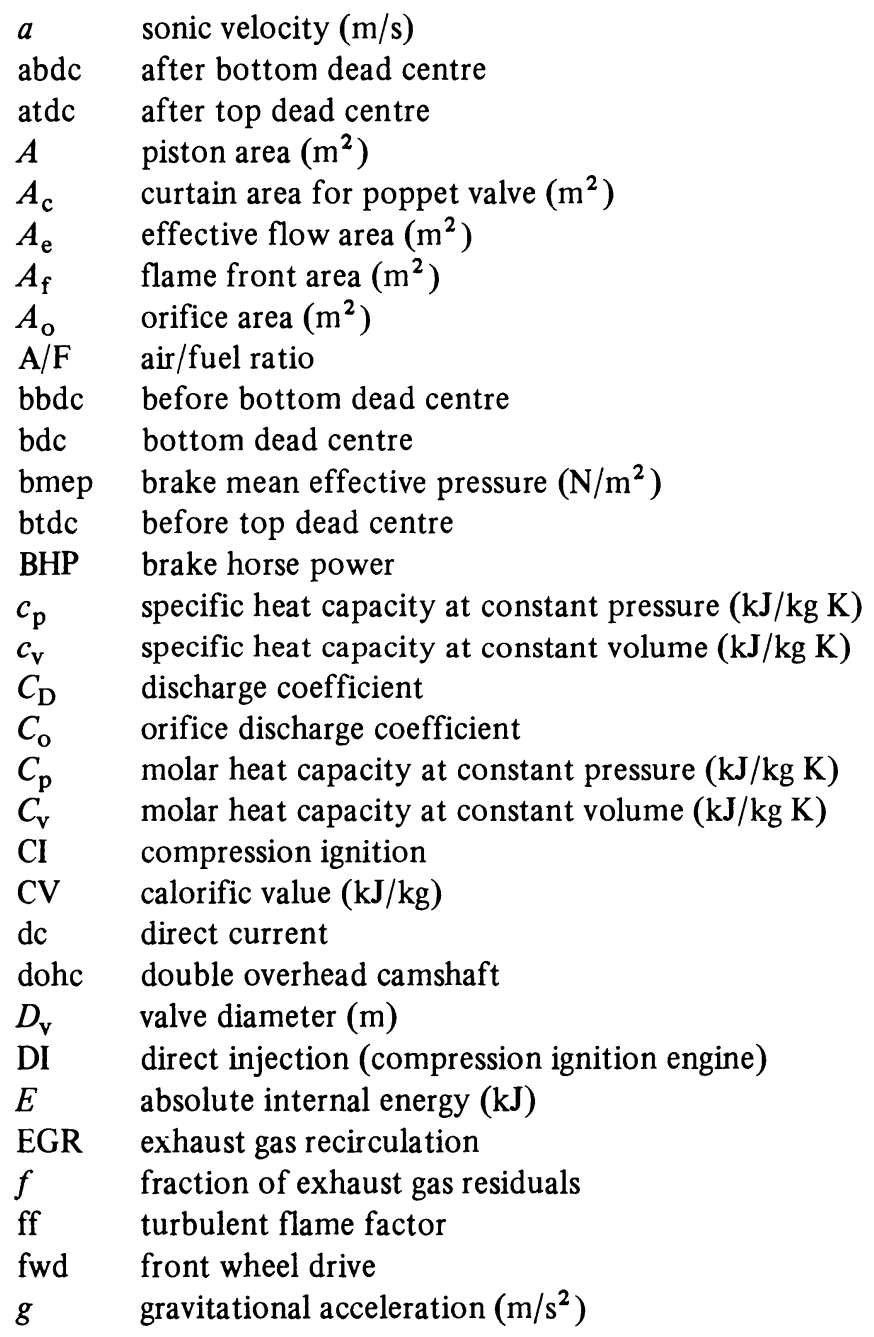




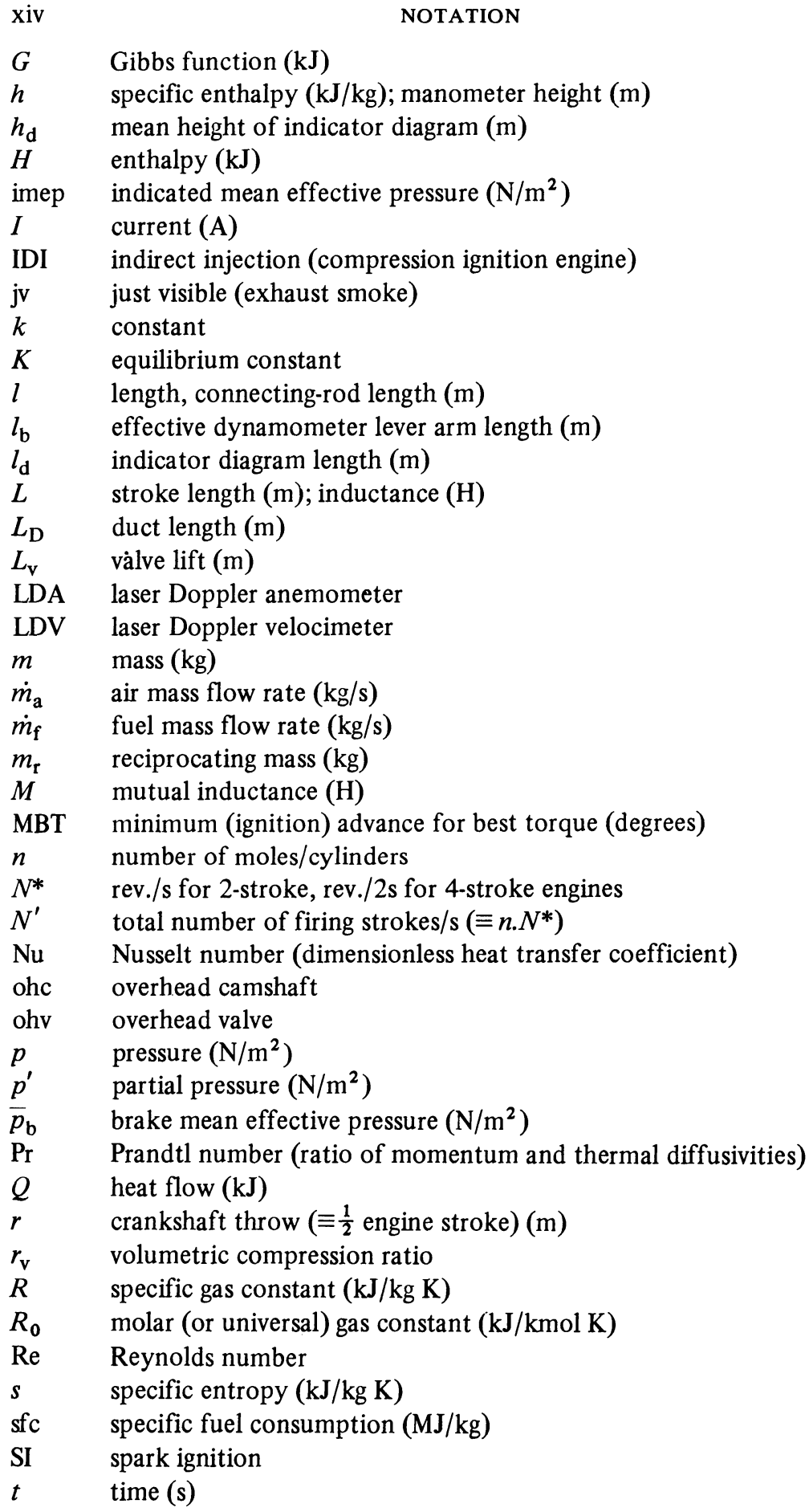


tdc top dead centre

$T$ absolute temperature (K); torque ( $\mathrm{N} \mathrm{m}$ )

$T_{0} \quad$ absolute temperature of the environment (K)

$U_{1} \quad$ laminar flame front velocity $(\mathrm{m} / \mathrm{s})$

$U_{\mathrm{t}} \quad$ turbulent flame front velocity $(\mathrm{m} / \mathrm{s})$

$v \quad$ velocity $(\mathrm{m} / \mathrm{s})$

$v_{\mathrm{p}} \quad$ mean piston velocity $(\mathrm{m} / \mathrm{s})$

$V \quad$ volume $\left(\mathrm{m}^{3}\right)$

$\dot{V}_{\text {a }} \quad$ volumetric flow rate of air $\left(\mathrm{m}^{3} / \mathrm{s}\right)$

$V_{\mathrm{s}} \quad$ engine swept volume $\left(\mathrm{m}^{3}\right)$

wmmp weakest mixture for maximum power

$W \quad$ work $(\mathrm{kJ})$

$\dot{W} \quad$ power $(\mathrm{kW})$

$W_{\mathrm{b}} \quad$ brake work $(\mathrm{kJ})$

$W_{\mathrm{c}} \quad$ compressor work $(\mathrm{kJ})$

$W_{\mathrm{f}} \quad$ friction work $(\mathrm{kJ})$

$W_{\mathrm{i}} \quad$ indicated work $(\mathrm{kJ})$

$W_{\mathrm{REV}}$ work output from a thermodynamically reversible process $(\mathrm{kJ})$

$W_{\mathrm{t}} \quad$ turbine work $(\mathrm{kJ})$

WOT wide open throttle

$x \quad$ a length (m); mass fraction

$\alpha \quad$ cut off (or load) ratio

$\boldsymbol{\gamma}$ ratio of gas heat capacities, $c_{\mathrm{p}} / c_{\mathrm{v}}$ or $C_{\mathrm{p}} / C_{\mathrm{v}}$

$\Delta H_{0} \quad$ enthalpy of reaction (combustion) $\equiv-\mathrm{CV}$

$\Delta p \quad$ pressure difference $\left(\mathrm{N} / \mathrm{m}^{2}\right)$

$\Delta \theta_{\mathrm{b}} \quad$ combustion duration (crank angle, degrees)

$\epsilon \quad$ heat exchanger effectiveness $=($ actual heat transfer $) /(\max$. possible heat transfer)

$\eta \quad$ efficiency

$\eta_{\mathrm{b}} \quad$ brake thermal efficiency $\equiv \eta_{\mathrm{o}}$

$\eta_{\mathrm{c}} \quad$ isentropic compressor efficiency

$\eta_{\text {Diesel }}$ ideal air standard Diesel cycle efficiency

$\eta_{\text {FA }} \quad$ fuel-air cycle efficiency

$\eta_{\mathrm{i}} \quad$ indicated (arbitrary overall) efficiency

$\eta_{\mathrm{m}} \quad$ mechanical efficiency

$\eta_{0} \quad$ arbitrary overall efficiency

$\eta_{\text {Otto }}$ ideal air standard Otto cycle efficiency

$\eta_{\mathrm{R}}$ rational efficiency, $w / W_{\mathrm{REV}}$

$\eta_{\mathrm{t}} \quad$ isentropic turbine efficiency

$\eta_{\mathrm{v}} \quad$ volumetric efficiency

$\theta \quad$ crank angle (degrees)

$\theta_{0} \quad$ crank angle at the start of combustion (degrees)

$\mu \quad$ dynamic viscosity $(\mathrm{N} \mathrm{s} / \mathrm{m})$

$\rho \quad$ density $\left(\mathrm{kg} / \mathrm{m}^{3}\right)$ 
$\rho_{\mathrm{u}} \quad$ density of the unburnt gas $\left(\mathrm{kg} / \mathrm{m}^{3}\right)$

$\phi \quad$ equivalence ratio $=$ (stoichiometric air/fuel ratio) $/($ actual air/fuel ratio) (note that sometimes the reciprocal definition is used in other publications)

$\omega$ specific humidity (kg water/kg dry air); angular velocity ( $\mathrm{rad} / \mathrm{s})$ 